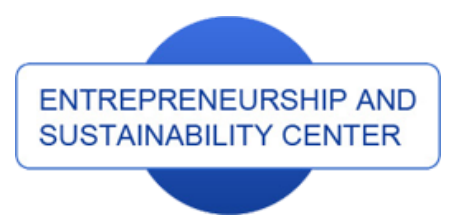

Publisher

http://jssidoi.org/esc/home

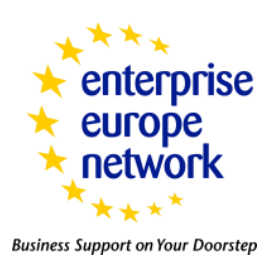

CASPA

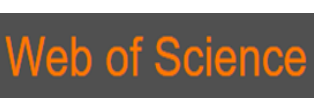

\title{
IMPORTANCE OF THE PROCESS OF TEACHING THE BASICS OF SOCIAL ENTREPRENEURSHIP FOR THE SUSTAINABLE DEVELOPMENT OF SOCIETY
}

\author{
Olga Voronkova ${ }^{\text {, }}$ Valeriy Nikishkin ${ }^{2}$, Irina Frolova ${ }^{3}$, Elena Matveeva ${ }^{4}$, \\ Gulnaz Murzagalina ${ }^{5}$, Ervena Kalykova ${ }^{6}$
}

\author{
${ }^{1}$ Altai state University, Lenina Str. 61, Barnaul, Russian Federation \\ ${ }^{2}$ Plekhanov Russian University of Economics (PRUE), Stremyanny Lane 36, 117997, Moscow, Russian Federation \\ ${ }^{3}$ Kazan Innovative University named after V.G. Timiryasov, Moskovskaya Street 42, Kazan, Russian Federation \\ ${ }^{4}$ I.M. Sechenov First Moscow State Medical University, Russian Federation, 119991, Moscow, Trubetskaya st., 8-2 \\ ${ }^{5}$ Sterlitamak Branch of Bashkir State University, Sterlitamak, Lenin Avenue, 49, Republic of Bashkortostan 453100, Russian \\ Federation \\ ${ }^{6}$ Kalmyk State University named after B.B. Gorodovikov, Elista, Pushkin Street, 11, Republic of Kalmykia, 358000, Russian \\ Federation \\ E-mails: *l olka2004@yandex.ru
}

Received 15 May 2019; accepted 14 October 2019; published 15 December 2019

\begin{abstract}
Self-realization in the professional sphere is one of the most important areas of human activity. In the conditions of socioeconomic crisis, the transition to market relations and strengthening of social stratification, it is important to involve business in solving major social problems. The paper substantiates the importance of the process of teaching unemployed women the basics of social entrepreneurship for their self-realization in this direction. Recommendations are presented on social entrepreneurship education, aimed primarily at unemployed women, creating a positive image of an entrepreneur organizing a socially oriented enterprise, and providing educational support to social entrepreneurs. An educational course "Social Entrepreneurship" has been developed, which can be implemented by regional employment services and non-governmental agencies to promote employment and self-realization of unemployed women.
\end{abstract}

Keywords: unemployed; education; unemployed women; social entrepreneurship; professional self-realization

Reference to this paper should be made as follows: Voronkova, O., Nikishkin, V., Frolova, I., Matveeva, E., Murzagalina, G., Kalykova, E. 2019. Importance of the process of teaching the basics of social entrepreneurship for the sustainable development of society. Entrepreneurship and Sustainability Issues, 7(2), 1048-1058. http://doi.org/10.9770/jesi.2019.7.2(18)

JEL Classifications: R13, M13

\section{Introduction}

The labor market and employment of Russian women in recent decades have undergone major changes. Women's unemployment in Russia is qualitatively different from unemployment in developed Western countries. The 


\section{ENTREPRENEURSHIP AND SUSTAINABILITY ISSUES}

ISSN 2345-0282 (online) http://jssidoi.org/jesi/

2019 Volume 7 Number 2 (December)

http://doi.org/10.9770/jesi.2019.7.2(18)

principal difference is that in the West, unemployment is an immanent phenomenon typical of the development of capitalist relations over several centuries. Accordingly, social protection policies for various groups of the unemployed, return of the released labor resources, and social adaptation to the conditions of employment have been developed and tested by life.

Russians, on the other hand, are faced with unemployment in a sharp, acute form after many decades of the guaranteed right to work and overall employment. Therefore, in Russia and in the West, the social and sociopsychological consequences of unemployment are fundamentally different in scale and strength. This is achieved by mass social depression, loss of confidence in the future. The long, stable impoverishment of the bulk of the population has led, in particular, to social discrimination against women and their discrimination in the field of work (Bekebayeva et al., 2019; Singareddy et al., 2019; Rahman and Bobkova, 2017a, b).

The problem of self-realization in the professional activity of an individual at the present stage of development of Russian society has become particularly acute. The problems of personal self-realization in social entrepreneurship are increasingly attracting the attention of researchers all over the world, which is determined by the importance of self-realization as a cultural component of human behavior in society and increased capabilities of science that can solve problems of high complexity (Dees, 1998; Harding, 2004; Koroles \& Berman, 2006; Alter, 2007; Dacin et al., 2010; Maksimova, 2015; Mauch \& Tarman, 2016; Kazieva, 2017).

According to foreign scholars, a social institution is a form of standardized expectations that govern individual behavior and social relationships (Bowles \& Gintis, 2002; Austin, 2006; Dorado, 2006; Miller \& Wesley, 2010; Hibbert et al., 2005; Dart, 2004; Trofimova et al., 2019). Social entrepreneurship can be considered as the most important state institution that performs an auxiliary function, helping the state to ensure the stable operation of society and certain social groups, in particular, unemployed women.

\section{Methodology}

The methodological basis of the study was the institutional approach. To solve research problems, theoretical research methods were used, in particular: interdisciplinary analysis, studying the theoretical state and degree of problem development, identifying the problem and its solutions, identifying key concepts reflecting the content of the issues under consideration, constructing theoretical concepts based on logical reasoning as mediated by the authors' professional experience.

The purpose of the paper is to substantiate the significance of the process of teaching unemployed women the basics of social entrepreneurship for their self-realization and development of social projects. As empirical research methods, the authors used the data of a sociological survey, statistics, and study of pedagogical experience. These methods allowed finding out the relationship between the process of education in the field of social entrepreneurship for unemployed women and the degree of their self-realization in professional activities.

\section{Results and Discussion}

\section{Significance of the study}

The significance of social entrepreneurship is that in today's socio-economic and political conditions, society requires a conscious and responsible approach to solving social problems from business entities, a developed sense of civic responsibility for vulnerable social groups and communities. Businesses should be involved in the activities of the institution of patronage and philanthropy in order to achieve social justice for other social groups and society as a whole. Currently, entrepreneurship is one of the most important social institutions that can assist government agencies in solving social problems through the development of urban and regional infrastructure, 


\section{ENTREPRENEURSHIP AND SUSTAINABILITY ISSUES}

ISSN 2345-0282 (online) http://jssidoi.org/jesi/

2019 Volume 7 Number 2 (December)

http://doi.org/10.9770/jesi.2019.7.2(18)

environmentally friendly activities, and work with socially vulnerable and low-income groups of the population. Consequently, recently this topic has become increasingly relevant both among domestic and foreign authors.

As a rule, it is women who often face difficulties both in finding a job and in the process of self-realization in professional activities. There are certain stereotypes about the inability of women to combine successful professional activities with a successful marriage and a full-fledged family. At the same time, most modern women want to be professionally successful, and unemployment negatively affects their mental and emotional state (Akhinov \& Rvachev, 2016; Hockers, 2006; Kuznetsova et al., 2019; Vasilev et al., 2018).

It is worth noting that many unemployed women could successfully realize their creative and productive potential in the emerging sphere of social entrepreneurship. The institution of social entrepreneurship addresses the most important needs by providing mutual assistance between members of the community. The development of the principles of social entrepreneurship is beneficial to the state, society, and business.

Today, the problem of employment of the working population primarily concerns women. Today, 33.9 million women work in Russia, or $48 \%$ of all workers. The demographic situation is such that the number of able-bodied women will gradually increase. Moreover, today, among the total number of all officially registered unemployed, the share of women is about 69\% (Moskovskaya, 2015).

More than 77 million women live in the Russian Federation, which is approximately $53 \%$ of the country's total population. The main reason for separating women into a specific social group that needs more social support is related to the ability of women to bear children, which is the basis for the viability of a particular society. At the same time, the generative capacity of women is the main cause of difficulties arising in the field of employment. Marriage and birth of children force women to interrupt production activities for some time.

Social entrepreneurship is an important economic activity that challenges the basic principles of economy. Thus, social entrepreneurship contributes to the active involvement of unemployed women in economic life. The selfrealization of unemployed women is possible only through full participation in community's life, when people get the power and resources to work together to improve their lives, strengthen their families and contribute to the development of society (Goloshchapova et al., 2018; Plaskova et al., 2017; Kovaltchuk et al., 2016; Tarman and Chigisheva, 2017; Prodanova et al., 2019).

The ideas of social entrepreneurship have recently become increasingly relevant. Using market-based methods to solve social problems, social entrepreneurship identifies two tasks: the creation of both social and economic values. Social enterprises seek to create value for customers; it is a concern for others that makes social entrepreneurship an important and significant direction.

\section{Features of social entrepreneurship}

The most important features of social entrepreneurship should be highlighted:

$>$ social entrepreneurship is a kind of balance between the social values and the economic component. Such interaction creates social and economic values, which distinguishes social entrepreneurship from traditional forms of business and from charity organizations;

$>$ social entrepreneurship arises in certain conditions, where traditional markets have failed, or where there is an institutional vacuum. A social entrepreneur should evaluate not only the risks associated with the development of a new type of activity but also the risks associated with the formation of new institutions that can support this type of business;

$>$ social entrepreneurship attracts unemployed women, mothers of many children and disabled people to work. 


\section{ENTREPRENEURSHIP AND SUSTAINABILITY ISSUES}

ISSN 2345-0282 (online) http://jssidoi.org/jesi/ 2019 Volume 7 Number 2 (December) http://doi.org/10.9770/jesi.2019.7.2(18)

Organizations related by their function to the sphere of social entrepreneurship are seen as the main goal not only in the accumulation of capital but also in solving social problems in accordance with accepted norms, values, and rules. Social entrepreneurship performs the following functions in society:

1) ensuring the processes of social solidarity and social justice;

2) promotion of social equality, which leads to the development of social integration and order in society;

3) attracting young people to solving social problems;

4) creating an informed and open society based on ethical standards and resistant to xenophobia;

5) development of social integration.

Table 1 presents the main areas and areas of activity of social entrepreneurs in Russia in 2018.

Table 1. Fields of activity of social entrepreneurs in Russia, 2018 (Federal Portal for Small and Medium-Sized Businesses, 2019)

\begin{tabular}{|c|c|c|}
\hline $\begin{array}{ll}\text { Rating } & \text { of } \\
\text { spheres } & \text { of } \\
\text { activity } & \end{array}$ & Direction of social entrepreneurship & $\begin{array}{l}\text { Share in the total volume of } \\
\text { activities } \\
\text { entrepreneurship, } \%\end{array}$ \\
\hline 1 & Projects in the field of education and children's leisure & 41 \\
\hline 2 & Employment of people in difficult life situations & 16 \\
\hline 3 & Improving the quality of life of vulnerable social groups & 7 \\
\hline 4 & $\begin{array}{l}\text { Improving the quality and accessibility of the quality of medical } \\
\text { services }\end{array}$ & 7 \\
\hline 5 & Making socially significant products & 6 \\
\hline 7 & Development of agriculture in remote regions & 5 \\
\hline 8 & Tourist and recreational services for vulnerable social groups & 5 \\
\hline 9 & Ecology projects & 4 \\
\hline 10 & Preservation and revival of the cultural and historical heritage of Russia & 3 \\
\hline 11 & Provision of public geriatric services & 3 \\
\hline 12 & Organization of affordable sports and recreational leisure & 3 \\
\hline
\end{tabular}

The main types of the functioning of a socially oriented business are the production of goods and the provision of socially significant works and services. Currently, the most relevant are the following areas of social entrepreneurship:

- Ecological business. Activities aimed at improving the environmental situation.

- Organization of employment for persons with disabilities.

- Organization of children's development and leisure (organization of children's events, creation of training groups, clubs, etc.).

- Organization of healthy and healthy leisure activities (cleaning and gardening of territories, making children's and sports grounds, organization of holidays, cultural events).

- Rehabilitation of citizens after traumatic situations.

Government agencies should develop a concept for the phased development of social entrepreneurship. To implement this concept, the following is needed:

1. campaigning in the media for the participation of entrepreneurs in charity events (Internet, television, radio), broadcasting information about tax incentives, training, counseling and other forms of state support for social entrepreneurs;

2. creation of the positive image of a social entrepreneur as an organizer of a socially oriented organization.

3. provision of legal support to social entrepreneurs;

4. development of a system of economic support for social entrepreneurship;

5. educational and informational support of social entrepreneurship organizations.

\section{Educational aspect of social entrepreneurship}

The educational component of social entrepreneurship for the target audience - unemployed women - can be represented by organizing meetings of future social entrepreneurs with regional authorities on cooperation, 


\section{ENTREPRENEURSHIP AND SUSTAINABILITY ISSUES}

ISSN 2345-0282 (online) http://jssidoi.org/jesi/

2019 Volume 7 Number 2 (December)

http://doi.org/10.9770/jesi.2019.7.2(18)

opening research centers and incubators, holding master classes to share the experience. Social entrepreneurship needs people with an active lifestyle, opinion leaders who can both generate and implement relevant, sociallyoriented business ideas.

During the research, it was revealed that:

- psychological personality traits (communicative, emotional, and others) of a professionally successful woman are specific and differ markedly from the psychological traits of an unemployed woman's personality.

- unemployed women have qualities that often impede successful self-realization in traditional business sectors.

- unemployed women can be successful in social entrepreneurship, since women have naturally developed empathy for people, and the ability to empathize is very important for the successful development of a socially oriented business.

The difficulties of self-realization of women are different because of the transient nature and mainly the solvability of the obstacles that arise. Unlike intractable difficulties, solvable difficulties can sometimes even contribute to successful self-realization, bringing the process of self-realization of unemployed women to a new level (Korableva et al., 2019a, b; Lafer and Tarman, 2019; Yiğit and Tarman, 2013).

\section{Self-realization of unemployed women}

Special educational programs can help unemployed women to overcome difficulties in self-realization. Vocational training for the unemployed is a scientifically based system of measures that includes three options for additional vocational education: vocational training, retraining, and advanced training carried out by sending employment services to increase the competitiveness of the unemployed in the labor market, overcome socioeconomic, situational and other types of maladjustment caused by job loss.

The problem of women's self-realization relates to socio-psychological and social problems of modern society. The study of theoretical material on this topic has shown that there are a number of problems affecting the effectiveness of the use of vocational education as a tool to reduce unemployment among women.

The existing difficulties of the educational process focused on unemployed women include a small number of areas of vocational training, retraining, and formation of new competencies (Prodanova et al., 2017; Dunets et al., 2019; Goryushkina et al., 2018; Mueller et al., 2019; Kovalenko et al., 2018a, b). The set of proposed specialties is formed taking into account the existing demand in the labor market and the organizational capacity of employment centers. The most common offers are jobs, but for unemployed people with higher education (mostly women), such options do not seem attractive.

The next important task is to duly fix the content of the curriculum correctly, taking into account the brevity of training (from 4 weeks to 8 months). The limited time and the compactness of the learning conditions give rise to a rigorous selection, a clear structuredness of the material presented, and a high concentration of its presentation. As a rule, training implies the presence of certain knowledge, skills and competencies of students. As a result, the following problem arises - the low level of readiness for the upcoming training in unemployed women reduces the productivity of this learning process (Pavlyuk et al., 2018; Yemelyanov et al., 2019; Bozhkova et al., 2019). As a result, employment service specialists often face the following typical situations:

1) unemployed women who applied to the employment service are prone to passive assistance measures, which are often ineffective in their choice (the job search time is slow, proposed vacancies do not meet expectations, etc.);

2) having chosen the initiative strategy of her development, an unemployed woman begins vocational training, but does not complete it;

3) an unemployed woman does a training program, but is experiencing difficulties with the further practical application of the obtained new competencies. 


\section{ENTREPRENEURSHIP AND SUSTAINABILITY ISSUES}

ISSN 2345-0282 (online) http://jssidoi.org/jesi/

2019 Volume 7 Number 2 (December)

http://doi.org/10.9770/jesi.2019.7.2(18)

The third situation examined demonstrates the mechanism of manifestation of "secondary" unemployment in the labor market. Secondary unemployment includes job seekers, retrained, but not working, not found a job, not employed in the labor market.

The situation related to secondary unemployment, in the authors' opinion, is one of the proofs that low motivation to master educational programs, difficulties in mastering new social roles can, on the one hand, increase the negative feelings of an unemployed woman associated with her attempts to overcome unemployment, and, on the other hand, strengthen the social and economic losses of the state (Rih, 1996; Defourny, 2012; Khalikov et al., 2018).

In this regard, the authors consider it important to expand the boundaries of the psychological and pedagogical component of the employment agencies, including psychological and pedagogical support for unemployed women, increasing the share of their participation in training programs in the areas of social entrepreneurship.

The organization of the educational process should take into account both the general characteristics of all unemployed women (experiencing personal crisis, complex manifestation of social maladjustment associated with job loss or its prolonged absence) and their differences due to socio-demographic characteristics (age, professional experience, type of nervous activities, etc.).

The effectiveness of training unemployed women in the basics of social entrepreneurship is closely linked to overcoming the psycho-physiological, socio-psychological, psychological, educational, and socio-economic barriers that impede the learning process (Shatunova et al., 2019). The elimination of these barriers will require preliminary targeted preparation of unemployed women for vocational training and the study of new material, and in the process of training they also need to be provided additional assistance.

Today, professional counseling and psychological assistance from employment agencies often occurs without taking into account the specific needs of unemployed women when choosing a strategic professional career.

To solve these problems, it is necessary to implement the following activities:

- introduction of socio-psychological recommendations for managers, teachers, and psychologists, contributing to the necessary changes in their own system of attitudes, beliefs, and expectations regarding different genders, as well as in the system of relationships and interactions with different genders in society;

- development and implementation of programs of social and psychological correction for girls and women, which help to adequately assess themselves and make informed life choices in their profession and personal life.

The state policy in the professional and employment spheres provides a set of measures aimed at enhancing the role of women in public life, stimulating their professional activities, as well as creating the conditions for combining career with family responsibilities.

At the same time, important areas of activity here are training and retraining of personnel, creation of new jobs and development of a system of social and socially significant works that allow taking into account the gender aspect. Today, the employment of unemployed women is developing in the food, processing and light industries, networks of organizations for the provision of social services, new jobs being created in the sphere of social services, that is, to a large extent in the sphere of social entrepreneurship.

When employing vulnerable groups of unemployed citizens, especially single and large family women raising minor children, children with disabilities, the authors suggest applying the practice of quoting jobs.

However, the most effective measure to mitigate the social consequences of unemployment and increase selfrealization is the vocational training of unemployed women in obtaining the necessary knowledge and competencies in the field of social entrepreneurship. After training, the level of employment and self-realization of women increases significantly. 
In the process of studying the possibilities of forming social entrepreneurship among unemployed women, the implementation of training programs on the basics of social entrepreneurship involving regional and city employment agencies is proposed.

The educational program "Social Entrepreneurship" consists of the following units:

1) Introduction to social entrepreneurship;

2) Identification and evaluation of social opportunities;

3) Legal regulation of social entrepreneurship;

4) Dynamic business models;

5) Marketing research of the social products and services market;

6) Search for investment for the development of social enterprises;

7) Opening and registration of social enterprises;

8) Strategy of social development of the enterprises;

9) Measuring the social impact of enterprises;

10) Basics of accounting;

11) Business and financial management of social enterprises;

10) Business ethics and communication.

Classes for each unit are held during one day and can be held not only in the on-site mode. For those who cannot attend classes, classes can be held online in the form of webinars (Kudinov et al., 2018).

Social entrepreneurship education programs for unemployed women should pay attention to studying the characteristics of social entrepreneurship both in general and in individual components of this activity, in particular, the ability to communicate, present their projects, interact with representatives of the business community and government officials, and fundraise.

\section{Conclusion}

The proposals will contribute to the study of the problems of self-realization of unemployed women in social entrepreneurship by obtaining the necessary education and the formation of new professional competencies. The practical application of this work may be associated with the creation of new training programs implemented by employment agencies, as well as psychological assistance to unemployed women in terms of their self-realization in professional activities.

Self-realization of unemployed women in their professional activities is a continuous process; at certain periods of life, the psychological characteristics of a person influence self-realization in the profession; at other times, selfrealization in professional activities affects psychological characteristics, that is, it has a dual relationship.

\section{References}

Akhinov G. A., Rvachev A. L. 2016. Questions of regulation of business in the conditions of development of market relations. Philosophy of economy, 4(106), 136-150.

Alter, S.K. (2007), Social Enterprise Typology, Virtue Ventures LLC.

Alvord, S.H., Brown, D.L. and Letts, C.W. 2004. Social entrepreneurship and societal transformation: An exploratory study. Journal of Applied Behavioural Science, 40, pp. 260-282.

Austin, J., Stevenson, H. and Wei-Skillern, J. 2006. Social and commercial entrepreneurship: Same, different, or both? Entrepreneurship Theory \& Practice, 30, pp. 1-22. 


\section{ENTREPRENEURSHIP AND SUSTAINABILITY ISSUES}

ISSN 2345-0282 (online) http://jssidoi.org/jesi/ 2019 Volume 7 Number 2 (December)

http://doi.org/10.9770/jesi.2019.7.2(18)

Bekebayeva, A. D., Nurbayev, Z. E., Nursultanova, L. N., Azmukhanova, A. M., \& Yerimbetova, K. M. 2019. Formation and development of women's non-governmental organisations in central Asia. Space and Culture, India, 6(5), 136-155. https://doi.org/10.20896/saci.v6i5.480

Bowles S., Gintis H. 2002. Prosocial Emotions. The Economy as an Evolving Complex System, 3, 339-364.

Bozhkova G.N., Shastina E.M., Kalimullina O.V., Shatunova O.V. 2019. Study of literary images of gifted characters in optional activities as a means to develop capable and talented youth. Space and Culture, India, 7:1, pp. 264- 273. https://doi.org/10.20896/saci.v7i1.463

Dacin P.A., Dacin M.T., Matear M. 2010. Social Entrepreneurship: Why we don't need a new theory and how we move forward from here. Academy of Management Perspectives, 24(3), 37-57.

Dart, R. 2004. The legitimacy of social enterprise, Nonprofit Management \& Leadership, 14(4), pp. 411-424.

Dees J. G. 1998. The meaning of «social entrepreneurship». Palo Alto, CA: Graduate School of Business, Stanford University, 124.

Defourny J. and Nyssens M. 2012. The EMES approach of social entrepreneurship in a comparative perspective, EMES European Research Network, no. 12(3).

Dorado, S. 2006. Social entrepreneurial ventures: different values so different process of creation, no? Journal of Developmental Entrepreneurship, 11(4), pp. 319-343.

Dunets, A., Latysheva, O., Bitter, N., Vakhrushev, I., Shichiyakh, R., \& Zhuruli, G. 2019. The economic and infrastructural basis for the development of tourist space: The essence, structure and typology. Journal of Environmental Management and Tourism, 10(2), 319-327. http://doi:10.14505/jemt.v10.2(34).05

Federal portal for small and medium-sized businesses. 2019. http://smb.gov.ru/measuresupport/programs/

Goloshchapova, L. V., Plaskova, N. S., Prodanova, N. A., Yusupova, S. Y., \& Pozdeeva, S. N. 2018. Analytical review of risks of loss of profits in cargo transportation. International Journal of Mechanical Engineering and Technology, 9(11), 1897-1902.

Goryushkina, N. E., Vakhrushev, I. B., Akhmetova, M. K., Otto, O. V., Pesotskaya, E. V., \& Voinova, N. E. 2018. The world hotel market: Current state and development trends. International Journal of Mechanical Engineering and Technology, 9(12), 618-627.

Harding, R. 2004. Social enterprise: The new economic engine? Business and Strategy Review, 15(4), $39-43$.

Hibbert, S., Hogg, G. and Quinn, T. 2005. Social entrepreneurship: Understanding consumer motives for buying The Big Issue. Journal of Consumer Behaviour, 4(3), pp. 159-172.

Hockerts, K. 2006. Entrepreneurial opportunity in social purpose business ventures, in Mair, J., Robinson, J., and Hockerts, K. (ed.), Social entrepreneurship, Palgrave Macmillan, Basingstoke, UK.

Kazieva L. U. 2017. Market, the subject of a socially oriented economy: institutional characteristics and principles of the organization. Economics and management: problems, solutions, 7(9), 9-12.

Khalikov, M. A., Maximov, D. A., \& Shabalina, U. M. 2018. Risk indicators and risk management models for an integrated group of enterprises. Journal of Applied Economic Sciences, 13(1), 52-64.

Korableva, O.N., Kalimullina, O.V., Mityakova, V.N. 2019a. Designing a System for Integration of Macroeconomic and Statistical Data Based on Ontology. Advances in Intelligent Systems and Computing, 998, p. 157-165

Korableva, O., Durand, T., Kalimullina, O., \& Stepanova, I. 2019b. Usability testing of MOOC: Identifying user interface problems. Paper presented at the ICEIS 2019 - Proceedings of the 21 st International Conference on Enterprise Information Systems, $2468-475$.

Korosec, R.L. and Berman, E.M. 2006. Municipal support for social entrepreneurship. Public Administration Review, 66 (3), pp. $448-462$.

Kovalenko, K. E., Goloshchapova, L. V., Polyakova, A. G., Erzinkyan, E. A., \& Murzagalina, G. M. (2018a). Approaches to social entrepreneurship in Russia and foreign countries. Journal of Entrepreneurship Education, 21(Special Issue 2) 


\section{ENTREPRENEURSHIP AND SUSTAINABILITY ISSUES}

ISSN 2345-0282 (online) http://jssidoi.org/jesi/

2019 Volume 7 Number 2 (December)

http://doi.org/10.9770/jesi.2019.7.2(18)

Kovalenko, K. E., Mueller, J. E., Khakimov, A. K., Yumashev, A. V., \& Khairullina, A. D. 2018b. Freelancing as a type of entrepreneurship: Advantages, disadvantages and development prospects. Journal of Entrepreneurship Education, 21(Special Issue 2)

Kovaltchuk, A. P., Dedusenko, E. A., Blinova, E. A., \& Miloradov, K. A. 2016. Concept and procedures of crisis management in Russian hotel enterprises. Journal of Environmental Management and Tourism, 7(3), 473-480. http://doi:10.14505/jemt.v7.3(15).13

Kudinov I. V., Kudinova G.F., Aitov V.F., Kadi S.V., Bannikova L.V., Voronkova O. Y. 2018. Information technologies in professional pedagogical education International Journal of Mechanical Engineering and Technology, 9(9), 1284-1292.

Kuznetsova, I. G., Voronkova, O. Y., Nimatulaev, M. M., Ruiga, I. R., Zhuruli, G. N., \& Levichev, V. E. (2019). Ensuring the national security of agriculture in the digital era through the formation of human capital. International Journal of Economics and Business Administration, 7, 558-569.

Lafer, S., \& Tarman, B. 2019. Editorial 2019: (2)1, Special Issue. Journal of Culture and Values in Education, 2(1), i-v. Retrieved from http://cultureandvalues.org/index.php/JCV/article/view/34

Light, P.C. 2006. Reshaping social entrepreneurship, Stanford Social Innovation Review, vol. Fall, pp. 46-51.

Maksimova, L. 2015. Business for people. Noviy kompanion, 4(817).

Mauch, J., Tarman, B. 2016. A historical approach to social studies laboratory method. Research in Social Sciences and Technology, (1)2, 55-66.

Miller T., Wesley C. 2010. Assessing Mission and Resources for Social Change: An Organizational Identity Perspective on Social Venture Capitalists' Decision Criteria. Entrepreneurship Theory and Practice, 34(4), 705-733.

Moskovskaya, A.A. 2015. Social entrepreneurship in Russia and in the world practice and research, Publishing House School of Economics, Moscow, Russia.

The Accounts Chamber of the Russian Federation. 2019. http://audit.gov.ru

Mueller, J. E., Chikunov, S. O., Fedchenko, E. A., \& Pronskaya, O. N. 2019. Innovative technologies in entrepreneurship education: The case of European and Asian countries. Journal of Entrepreneurship Education, 22(1)

Pavlyuk, A. V., Hasanov, E. L., Sverdlikova, E. A., \& Kadyrov, M. A. 2018. Institutional mechanisms for implementation of entrepreneurial potential of the population of the region. Journal of Applied Economic Sciences, 13(7), 2052-2075.

Plaskova, N. S., Prodanova, N. A., Zatsarinnaya, E. I., Korshunova, L. N., \& Chumakova, N. V. 2017. Methodological support of organizations implementing innovative activities investment attractiveness estimation. Journal of Advanced Research in Law and Economics, 8(8), 2533-2539. https://doi.org/10.14505/jarle.v8.8(30).25

Prodanova, N. A., Smolentsev, V. M., Norkina, A. N., Shukshina, Y. A., \& Polyanskaya, O. A. 2017. Formation of system of internal control and features its functioning in the innovative development of industrial enterprises. International Journal of Applied Business and Economic Research, 15(13), 179-189.

Prodanova, N. A., Trofimova, L. B., Korshunova, L. N., Kamolov, S. G., Trapaidze, K. Z., \& Pavlyuk, A. V. 2019. The methods and evaluation of RIC integrated business indicators. International Journal of Innovative Technology and Exploring Engineering, 8(10), 18891894. https://doi.org/10.35940/ijitee.J9242.0881019

Rahman, P. A., \& Bobkova, E. Y. 2017a. The reliability model of the fault-tolerant computing system with triple-modular redundancy based on the independent nodes. Paper presented at the Journal of Physics: Conference Series, 803(1) https://doi.org/10.1088/1742$\underline{6596 / 803 / 1 / 012125}$

Rahman, P.A., \& Bobkova, E.Yu. 2017b. The reliability model of the fault-tolerant border routing with two Internet services providers in the enterprise computer network. Paper presented at the Journal of Physics: Conference Series, 803(1) https://doi.org/10.1088/1742$\underline{6596 / 803 / 1 / 012124}$

Rih A. 1996. Economic ethics. Moscow, 810. 


\section{ENTREPRENEURSHIP AND SUSTAINABILITY ISSUES}

ISSN 2345-0282 (online) http://jssidoi.org/jesi/

2019 Volume 7 Number 2 (December)

http://doi.org/10.9770/jesi.2019.7.2(18)

Shatunova O., Anisimova T., Sabirova F., Kalimullina O. 2019. STEAM as an Innovative Educational Technology. Journal of Social Studies Education Research, 10(2), 131-144.

Singareddy, R. R. R., Ranjan, P., Balamurugan, A., \& Shabana, C. 2019. Financial inclusion remodeling: Including the excluded masses. Space and Culture, India, 6(5), 178-188. https://doi.org/10.20896/SACI.V6I5.375

Tarman, B., \& Chigisheva, O. 2017. Transformation of educational policy, theory and practice in post-soviet social studies education. Journal of Social Studies Education Research, 8(2), I-IV. https://doi.org/10.17499/jsser.93128

Trofimova, L., Prodanova, N., Korshunova, L., Savina, N., Ulianova, N., Karpova, T., \& Shilova, L. 2019. Public sector entities' reporting and accounting information system. Journal of Advanced Research in Dynamical and Control Systems, 11(8 Special Issue), 416-424.

Vasilev, B. U., Grigorev, P. S., \& Shulgenko, V. M. 2018. Configuration and energy supply of promising types of underwater pumping complexes for transportation of hydrocarbons from the shelf. Neftyanoe Khozyaystvo - Oil Industry, (3), 77-81. http://doi:10.24887/0028$\underline{2448-2018-3-77-81}$

Yemelyanov, V. A., Fatkulin, A. R., Nedelkin, A. A., Titov, V. A., \& Degtyarev, A. V. 2019. Software for weight estimation of the transported liquid iron. Paper presented at the Proceedings of the 2019 IEEE Conference of Russian Young Researchers in Electrical and Electronic Engineering, ElConRus 2019, 381-384. http://doi:10.1109/EIConRus.2019.8657011

Yiğit, M, Tarman, B. 2013. Degerler Eğitimimin ilköğretim 4. Ve 5. Sınıf Sosyal Bilgiler Ders Kitaplarindaki Yeri ve Önemi (The Place and Importance of Values Education in 4.th and 5th. Grade Primary School Social Studies Textbooks). Journal of Social Studies Education Research, 4 (2), 79-102. Retrieved from http://dergipark.gov.tr/jsser/issue/19101/202712

Olga VORONKOVA, Doctor of Economics, Professor of management, business organization and innovation Department, Altai state University. Has the status of an expert of the Eurasian technological platform "Technologies of food and processing industry of agriculture - healthy food". Research interests - sustainable development of territories, innovation, technological and social entrepreneurship, "green" economy.

ORCID ID: $\underline{\text { https://orcid.org/0000-0002-3106-4643 }}$

Valeriy NIKISHKIN, Doctor of Economics, Professor. Director of the Educational and Scientific Center for retraining and advanced training of teachers of the higher school of the Plekhanov Russian University of Economics. He graduated from the Faculty of Economic Cybernetics, postgraduate study of CEA. G.V. Plekhanov (Department of Economics of Commerce).

Research interests: Specializes in the field of applied marketing, is engaged in consulting retailers, takes an active part in international and Russian marketing projects.

ORCID ID: https://orcid.org/0000-0002-3310-6421 


\section{ENTREPRENEURSHIP AND SUSTAINABILITY ISSUES}

ISSN 2345-0282 (online) http://jssidoi.org/jesi/

2019 Volume 7 Number 2 (December)

http://doi.org/10.9770/jesi.2019.7.2(18)

Irina FROLOVA is the PhD (Sociology), Associate Professor, Deputy Director on scientific work Kazan Innovative University named after V.G. Timiryasov, Kazan, Russia. Research interests: entrepreneurship and regional development; innovation and small firms; small firm internationalization; sustainability.

ORCID ID: https://orcid.org/0000-0002-8707-6336

Elena MATVEEVA, Senior Lecturer, Department of orthopaedic dentistry I.M. Sechenov First Moscow State Medical University. Currently engaged in teaching clinical dentistry for students and postgraduate and research on rehabilitation of patients with anomalies of the lip and palate. Research interests: diseases of the temporomandibular joint, innovation in clinical dentistry, interdisciplinary approach. ORCID ID: http://orcid.org/0000-0002-2105-8880

Gulnaz MURZAGALINA, candidate of economic Sciences, associate Professor, chair of accounting and auditing Sterlitamak branch of Bashkir state University. Currently, he is the Dean of the faculty of Economics. He is engaged in teaching economic and management disciplines, as well as research in the field of business Economics.

Research interests: management, entrepreneurship, entrepreneurship training, regional development, accounting and auditing.

ORCID ID: http://orcid.org/0000-0002-1074-2759

Ervena KALYKOVA - PhD in Philology, Associate Professor, Department of Foreign Languages and General Linguistics, Kalmyk State University named after B.B. Gorodovikov. Currently engaged in teaching English on Economics and Management, Business English at the Faculty of Economics of KalmSU.

Research interests: management, entrepreneurship, social entrepreneurship, entrepreneurship education, linguistic culture, conceptualization.

https://orcid.org/0000-0001-7084-7854

Register for an ORCID ID:

https://orcid.org/register

Copyright (C) 2019 by author(s) and VsI Entrepreneurship and Sustainability Center

This work is licensed under the Creative Commons Attribution International License (CC BY).

http://creativecommons.org/licenses/by/4.0/

c) (†) Open Access 